\title{
Lengthy suppression of vascular proliferation by a chymase inhibitor in dog grafted veins
}

Koutaro Tsunemi, MD, a,b Shinji Takai, PhD, ${ }^{a}$ Masayoshi Nishimoto, MD, ${ }^{a, b}$ Atsushi Yuda, MD, ${ }^{a, b}$ Denan Jin, MD, ${ }^{a}$ Masato Sakaguchi, PhD, ${ }^{\mathrm{a}}$ Yoshihide Sawada, MD, ${ }^{\mathrm{b}}$ Kunio Asada, MD, ${ }^{\mathrm{b}}$ Keiichiro Kondo, MD, ${ }^{\mathrm{b}}$ Shinjiro Sasaki, MD, ${ }^{\mathrm{b}}$ and Mizuo Miyazaki, MD, ${ }^{a}$ Osaka, Japan

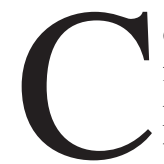

oronary artery bypass grafting $(\mathrm{CABG})$ has been performed on patients with ischemic heart disease to improve mortality and morbidity. In CABG the internal thoracic artery (ITA) and saphenous vein (SV) are commonly used as bypass conduits. However, the patency of venous grafts is worse than that of arterial grafts, ${ }^{1-4}$ and its mechanism has been unclear. This stenosis, called vein graft disease, is a problem to be addressed clinically. $5,6 \mathrm{CABG}$ with several arterial graft conduits, such as the radial artery, right gastroepiploic artery, and inferior epigastric artery in addition to the ITA, is clinically used to avoid vein graft disease. ${ }^{7,8}$ However, the use of venous grafts is not yet advisable for patients who require multiple coronary revascularization or for patients undergoing a second operation. Consequently, the improvement in venous graft patency might result in further improvements in mortality and morbidity.

Angiotensin II is known to play crucial roles in the proliferation of vascular tissue in addition to the regulation of blood pressure. ${ }^{9}$ It is known that angiotensin II is generated from angiotensin I by both angiotensin-converting enzyme (ACE) and chymasein the vascular tissue of human subjects, monkeys, dogs, and hamsters. ${ }^{10-13}$ Our recent studies showed that chymase-dependent angiotensin II plays an important role in the development of vascular proliferation in grafted veins. ${ }^{14,15}$ For example, we demonstrated that treatment with a chymase inhibitor, Suc-Val-Pro-Phe $\mathrm{P}^{\mathrm{P}}(\mathrm{Oph})_{2}$, to the vein only once before grafting could prevent the intimal hyperplasia in grafted veins 7 days after the operation in a dog model. ${ }^{16}$ However, it has been unclear how long a chymase inhibitor used only once during the operation will suppress intimal hyperplasia in dog grafted veins. In this study we investigated the long-term effect of the chymase inhibitor Suc-Val-Pro-Phe ${ }^{\mathrm{P}}(\mathrm{OPh})_{2}$ on intimal hyperplasia in dog grafted veins after bypass surgery.

From the Departments of Pharmacology a and Thoracic and Cardiovascular Surgery, ${ }^{\text {b }}$ Osaka Medical College, Osaka, Japan.

Received for publication Dec 14, 2001; accepted for publication March 24, 2002.

Address for reprints: Mizuo Miyazaki, MD, Department of Pharmacology, Osaka Medical College, 2-7 Daigaku-cho, Takatsuki City, Osaka 569-8686,

Japan (E-mail: pha010@art.osaka-med.ac.jp).

J Thorac Cardiovasc Surg 2002;124:621-5

Copyright $\odot 2002$ by The American Association for Thoracic Surgery

$0022-5223 / 2002 \$ 35.00+0 \quad \mathbf{1 2 / 5 4 / 1 2 5 1 6 4}$

doi: $10.1067 / \mathrm{mtc} .2002 .125164$

\section{Methods}

Drug. A specific chymase inhibitor, Suc-Val-Pro-Phe ${ }^{\text {p }}$ $(\mathrm{OPh})_{2},{ }^{17}$ was a gift from Dr Oleksystyn (Wroclaw Technical University, Poland).

Animal treatment. Twelve beagle dogs weighing 8 to 10 $\mathrm{kg}$ were obtained from Japan SLC (Shizuoka, Japan). The animals were anesthetized with sodium pentobarbital (35 $\mathrm{mg} / \mathrm{kg}$ administered intravenously). The right external jugular vein was removed and was infiltrated for 20 minutes in saline containing isosorbide dinitrate $(50 \mathrm{mg} / \mathrm{mL})$ and dipyridamole $(100 \mathrm{mg} / \mathrm{mL})$, which were used as agents for vascular dilation and antiplatelet action, respectively. Heparin $(200 \mathrm{U} / \mathrm{kg})$ was injected into the femoral vein as an antiplatelet drug, and then the vein was grafted to the ipsilateral artery. In the group treated with the chymase inhibitor, the vein was infiltrated for 20 minutes in the solution used for the placebo group but with the addition of Suc-Val-Pro-Phe ${ }^{\mathrm{P}}(\mathrm{OPh})_{2}(10 \mu \mathrm{mol} / \mathrm{L})$. Then the vein was grafted to the ipsilateral carotid artery. The nonsurgical dogs were used as a control group. The experimental procedures for animals were in accordance with the Guide for the Care and Use of Laboratory Animals (Animal Research Laboratory, Osaka Medical College).

Preparation of vascular tissue. Three months after bypass surgery, the grafted animals (each group comprised 4 dogs) were anesthetized with sodium pentobarbital (35 $\mathrm{mg} / \mathrm{kg}$ administered intravenously), and the grafted veins were removed. Four dogs not undergoing operations used as a control group were anesthetized with sodium pentobarbital $(35 \mathrm{mg} / \mathrm{kg}$ administered intravenously), and the right external jugular veins were removed.

Extraction for enzyme assay. The grafted and control veins were minced and homogenized in 10 volumes (wt/vol) of $20 \mathrm{mmol} / \mathrm{L} \mathrm{Na}$-phosphate buffer ( $\mathrm{pH} \mathrm{7.4).} \mathrm{The} \mathrm{homoge-}$ nate was centrifuged at 15,000 rpm for 30 minutes, and the supernatant was discarded. These steps were repeated twice. The pellets were resuspended and homogenized in 5 volumes (wt/vol) of $10 \mathrm{mmol} / \mathrm{L} \mathrm{Na-phosphate} \mathrm{buffer} \mathrm{(pH} \mathrm{7.4)}$ containing $2 \mathrm{~mol} / \mathrm{L} \mathrm{KCI}$ and $0.1 \%$ Nonidet P-40 (vol/vol). The homogenate was stored overnight at $4{ }^{\circ} \mathrm{C}$ and then centrifuged at 15,000 rpm for 30 minutes. The supernatant was used as the tissue extract for the measurement of ACE and chymase activities. 

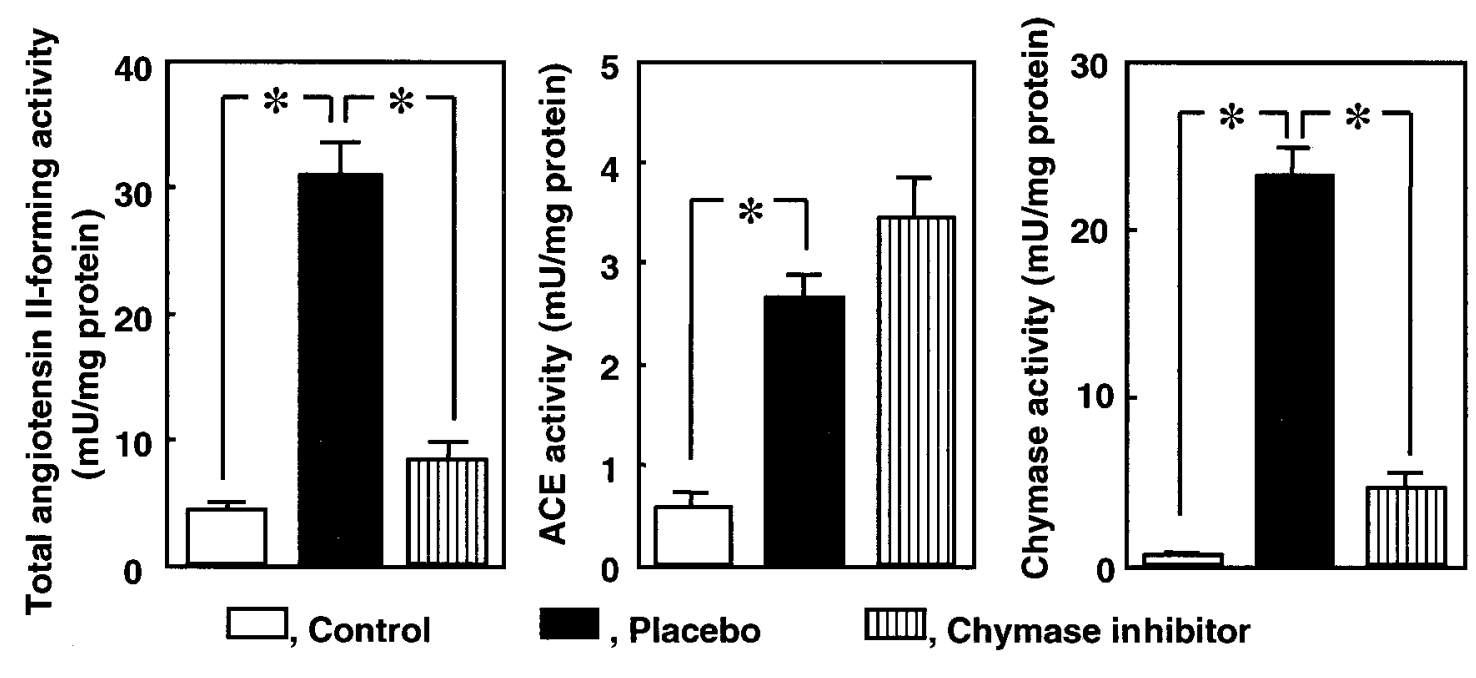

Figure 1. ACE and chymase activities in control veins, placebo-treated veins, and chymase inhibitor-treated veins. Each bar represents mean value \pm SEM $(n=4) .{ }^{*} P<.05$ versus placebo-treated group.

Measurements of enzyme activities. ACE activity was measured by incubating the tissue extracts for 1 hour at $37^{\circ} \mathrm{C}$ with $5 \mathrm{mmol} / \mathrm{L}$ hippuril-His-Leu as a substrate in 100 $\mathrm{mmol} / \mathrm{L}$ phosphate buffer $(\mathrm{pH} 8.3)$ containing $800 \mathrm{mmol} / \mathrm{L}$ $\mathrm{NaCl} .{ }^{15}$ The enzyme reaction was terminated by addition of $3 \%$ metaphosphoric acid (wt/vol), and the reaction mixture was placed in ice water for 10 minutes. After centrifugation of the mixture at 15,000 rpm for 5 minutes, we applied 50 $\mu \mathrm{L}$ of the supernatant to an octadecyl silica reversed-phase column $(4.6 \mathrm{~mm} \times 25 \mathrm{~cm}$; Tohso, Tokyo, Japan) that had been equilibrated with $10 \mathrm{mmol} / \mathrm{L} \mathrm{KH}_{2} \mathrm{PO}_{4}$ and $\mathrm{CH}_{3} \mathrm{OH}$ $(1: 1, \mathrm{pH} 3.0)$ and eluted it with the same solution at a rate of $0.3 \mathrm{~mL} / \mathrm{min}$. Hippuric acid was detected by means of ultraviolet absorbance at $228 \mathrm{~nm}$. One unit of ACE activity was defined as the amount of enzyme that cleaved $1 \mu \mathrm{mol}$ of hippuric acid/min.

Chymase activity was measured by incubating the tissue extracts for 1 hour at $37^{\circ} \mathrm{C}$ with $4 \mathrm{mmol} / \mathrm{L}$ angiotensin $\mathrm{I}$ in $150 \mathrm{mmol} / \mathrm{L}$ borax-borate buffer $(\mathrm{pH} 8.5)$ containing 5 $\mathrm{mmol} / \mathrm{L}$ ethylenediamine tetraacetic acid, $8 \mathrm{mmol} / \mathrm{L}$ dipyridyl, and $0.77 \mathrm{mmol} / \mathrm{L}$ diisopropylfluorophosphate, as described previously. ${ }^{15}$ The enzyme reaction was terminated by addition of $15 \%$ trichloroacetic acid (wt/vol), and the reaction mixture was placed in ice water for 10 minutes. After centrifugation of the reaction mixture at 15,000 rpm for 5 minutes, we applied $50 \mu \mathrm{L}$ of the supernatant to an octadecyl silica reversed-phase column (ODS 80-Tm, 4.6 $\mathrm{mm} \times 25 \mathrm{~cm}$; Tohso) that had been equilibrated with $30 \%$ methanol in $10 \mathrm{mmol} / \mathrm{L}$ phosphoric acid and eluted it with a linear gradient of $30 \%$ to $90 \%$ methanol in $10 \mathrm{mmol} / \mathrm{L}$ phosphoric acid at a rate of $1 \mathrm{~mL} / \mathrm{min}$. Angiotensin II was detected by means of ultraviolet absorbance at $226 \mathrm{~nm}$. One unit of chymase activity was defined as the amount of enzyme that cleaved $1 \mu \mathrm{mol}$ of angiotensin II/min.
Total angiotensin II-forming activity was measured by incubating tissue extracts for 30 minutes at $37^{\circ} \mathrm{C}$ with 4 $\mathrm{mmol} / \mathrm{L}$ angiotensin $\mathrm{I}$ in a $20 \mathrm{mmol} / \mathrm{L}$ Tris- $\mathrm{HCl}$ buffer containing $0.1 \%$ Triton $\mathrm{X}-100(\mathrm{pH} 8.5)$. The reaction was terminated by the addition of $15 \%$ trichloroacetic acid, and then the mixture was centrifuged at $20,000 \mathrm{rpm}$ for 5 minutes at $4{ }^{\circ} \mathrm{C}$. The supernatant $(50 \mu \mathrm{L})$ was applied to a reversed-phase column (ODS 80-Tm) that was equilibrated with $30 \% \mathrm{CH}_{3} \mathrm{OH}$ in $10 \mathrm{mmol} / \mathrm{L}$ phosphoric acid and eluted with a linear gradient of $30 \%$ to $90 \% \mathrm{CH}_{3} \mathrm{OH}$ in $10 \mathrm{mmol} / \mathrm{L}$ phosphoric acid at a rate of $1 \mathrm{~mL} / \mathrm{min}$. Angiotensin II was detected by means of ultraviolet absorbance at $226 \mathrm{~nm}$. One unit of chymase activity was defined as the amount of enzyme that cleaved $1 \mu \mathrm{mol}$ of angiotensin II/min.

The protein concentration was assayed with BCA Protein Assay Reagent (Pierce, Rockford, Ill) by using bovine serum albumin as a standard.

Histologic analysis of vascular tissue. The vessel segments were fixed in $10 \%$ neutral buffered formalin, embedded in paraffin, and cut into 5- $\mu \mathrm{m}$-thick sections to minimize the variance of neointima formation in the grafted veins. These sections were stained with van Gieson's elastic stain, and the cross-sectional areas of the intima and media were quantified with an image analysis system (VM-30; Olympus Optical Co, Tokyo, Japan).

Statistical analysis. All experiments were done with 4 dogs per group. Statistical analysis was performed by means of 1-way analysis of variance, followed by the Fisher protected least significant difference. Data are expressed as means \pm SEM.

\section{Results}

ACE and chymase activities. The ACE activity in grafted veins in the placebo-treated group was significantly 
higher than that in the control group, and it was not affected by treatment with the chymase inhibitor (control group, $0.57 \pm 0.15 \mathrm{mU} / \mathrm{mg}$ of protein; placebo-treated group, $2.68 \pm 0.19 \mathrm{mU} / \mathrm{mg}$ of protein; chymase inhibitor-treated group, $3.46 \pm 0.39 \mathrm{mU} / \mathrm{mg}$ of protein; Figure 1).

The chymase activity in the grafted veins in the placebotreated group was significantly higher than that in the control group, and it was significantly reduced by treatment with the chymase inhibitor (control group, $0.67 \pm 0.05$ $\mathrm{mU} / \mathrm{mg}$ of protein; placebo-treated group, $23.25 \pm 1.59$ $\mathrm{mU} / \mathrm{mg}$ of protein; chymase inhibitor-treated group, $4.62 \pm$ $0.99 \mathrm{mU} / \mathrm{mg}$ of protein; Figure 1).

Total angiotensin II-forming activity. The total angiotensin II-forming activity in the placebo-treated group was significantly higher than that in the control group, and it was significantly reduced by treatment with the chymase inhibitor (control group, $4.37 \pm 0.68 \mathrm{mU} / \mathrm{mg}$ of protein; placebotreated group, $31.02 \pm 2.56 \mathrm{mU} / \mathrm{mg}$ of protein; chymase inhibitor-treated group, $8.39 \pm 1.48 \mathrm{mU} / \mathrm{mg}$ of protein; Figure 2).

Intimal area, medial area, and ratio of intimal area to medial area. As shown in Figure 3 in typical sections, the chymase inhibitor clearly suppressed the intimal area. The intimal areas of the control group, placebo-treated group, and chymase inhibitor-treated group were $0.27 \pm 0.04$, $6.92 \pm 0.13$, and $1.58 \pm 0.10 \mathrm{~mm}^{2}$, respectively (Figure 4). The intimal area in the placebo-treated group significantly increased compared with that of the control group, and it was significantly decreased by treatment with the chymase inhibitor. The ratio of intimal area to medial area in the placebo-treated group was significantly increased compared with that in the control group, and it was also decreased by treatment with the chymase inhibitor (Figure 4).

\section{Discussion}

In the present study we demonstrated that direct and single infiltration of grafting veins to a chymase inhibitor maintained suppression of chymase activity and vascular proliferation 3 months after bypass surgery. Previously, the characterization of the specific chymase inhibitor we used, Suc-Val-Pro-Phe $\mathrm{P}^{\mathrm{P}}(\mathrm{OPh})_{2}$, was reported by Oleksyszyn and Powers. ${ }^{17}$ The half-degradative time of Suc-Val-Pro-Phe ${ }^{\mathrm{P}}(\mathrm{OPh})_{2}$ is approximately 20 hours in human plasma. In addition, we confirmed that chymase inhibitors, both chymostatin and Suc-Val-Pro-Phe ${ }^{\mathrm{P}}(\mathrm{OPh})_{2}$, dose-dependently suppressed the angiotensin I-induced vascular contraction in isolated dog arteries in the presence of an ACE inhibitor. ${ }^{14}$ The inhibitory concentration of $50 \%$ values of Suc-Val-Pro-Phe ${ }^{\mathrm{P}}$ $(\mathrm{OPh})_{2}$ in dog arteries was $2.8 \mathrm{nmol} / \mathrm{L}$, and the inhibitory concentration of $50 \%$ values of Suc-Val-Pro-Phe ${ }^{\mathrm{p}}(\mathrm{OPh})_{2}$ in dog arteries was about 35 times higher than that of chymostatin. These findings suggest that Suc-Val-Pro-Phe ${ }^{\mathrm{P}}(\mathrm{OPh})_{2}$ might be a stable and powerful chymase inhibitor. In fact, the inhibition by the chymase inhibitor was maintained fully up to 3 months after the operation in this study, although the inhibitor was used only during the operation and not continuously. It is reported that chymase, an

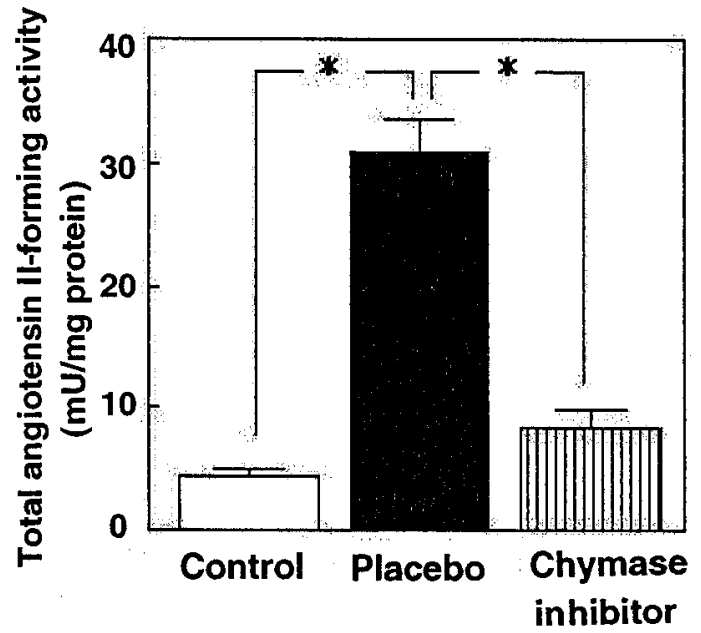

Figure 2. Total angiotensin II-forming activity in control veins, placebo-treated veins, and chymase inhibitor-treated veins. Each bar represents mean value \pm SEM $(n=4) .{ }^{*} P<.05$ versus placebo-treated group.

enzyme that is present in mast cell granules, is released immediately from the granules on strong stimulation, binds to extracellular matrix, and continues to function for several weeks. ${ }^{18,19}$ Mast cells in the grafted vessels were activated after the operation, indicating that chymase was bound to the extracellular matrix immediately after the operation. ${ }^{16}$ The chymase inhibitor used in this study functions irreversibly, which means that the inhibitor, once bound to the enzyme, continues to inhibit it for a long time. On the other hand, chymase is also reported to activate stem cell factor, a typical cytokine that has the ability to induce accumulation of mast cells. ${ }^{20}$ Inhibition of chymase activity is thought to prevent the accumulation of mast cells and resulted in reducing chymase activity. Therefore, up to 3 months after the operation, the chymase activity is thought to be fully inhibited by treatment with the chymase inhibitor.

Angiotensin II plays an important role in vascular proliferation through the induction of extracellular matrix and growth factors, both of which participate in the first stages of the repair process. ${ }^{21,22}$ For example, in a rat model neointima formation in vessels injured by a catheter was prevented with an angiotensin II type 1 receptor antagonist, and the expression of extracellular matrix and growth factors was also suppressed. ${ }^{23}$ Such findings were also reported with an ACE inhibitor in the rat model. ${ }^{24}$ However, clinical trials of ACE inhibitor for preventing restenosis after percutaneous transluminal coronary angioplasty were unsuccessful. $^{25}$ In graft experimental models an ACE inhibitor was effective in preventing vascular proliferation in rats, whereas in baboons it was not. ${ }^{26,27}$ Such species differences in the effects of ACE inhibitors on neointimal formation might depend on species differences in the angiotensin II-forming pathways. Rat vascular tissues contain ACE as the only angiotensin II-forming enzyme, whereas vascular tissues of human subjects, monkeys, dogs, and hamsters contain chymase in addition to ACE as angiotensin II-forming enzymes. ${ }^{10-13}$ In dog vessels injured by a catheter, an angiotensin II type $1\left(\mathrm{AT}_{1}\right)$ receptor antagonist was effective in 

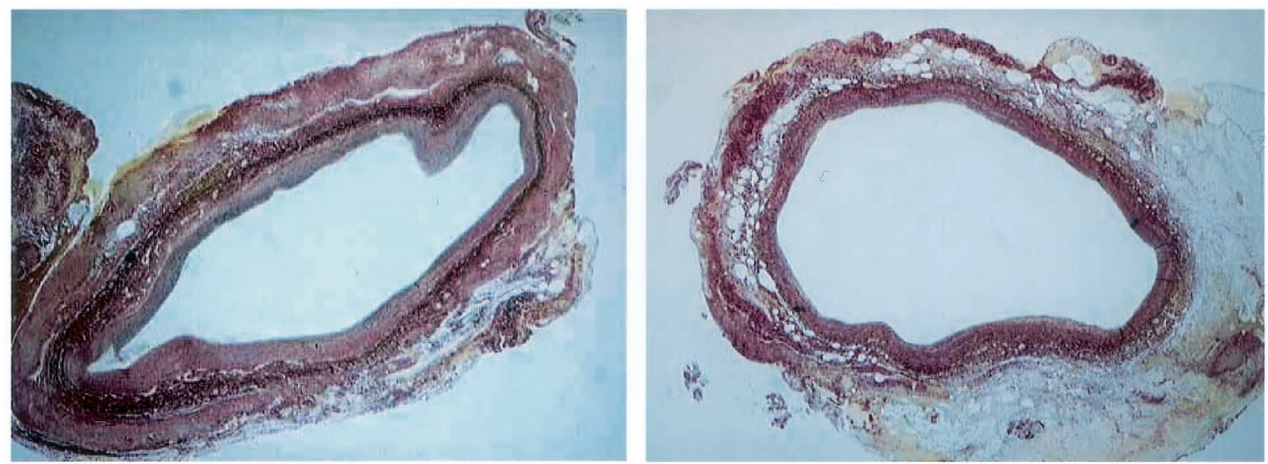

Figure 3. Typical histologic cross-sections of the grafted veins treated with placebo (left) and chymase inhibitor (right) stained with elastica-van Gieson stain.
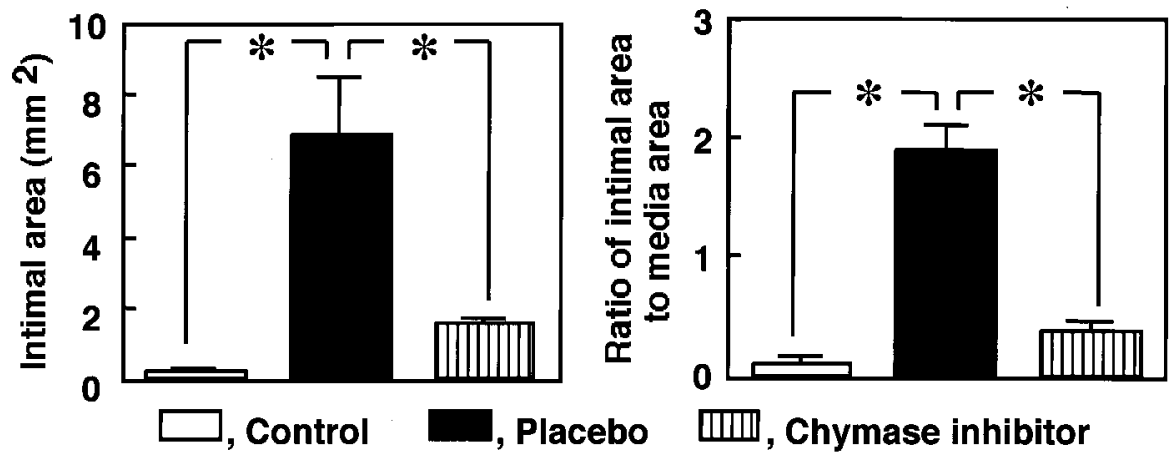

Figure 4. The intimal area and ratio of intimal area to medial area in control veins, placebo-treated veins, and chymase inhibitor-treated veins. Each bar represents mean value \pm SEM $(n=4)$. ${ }^{*} P<.05$ versus placebo-treated group.

preventing the intimal formation, but an ACE inhibitor was ineffective. ${ }^{28,29}$ Therefore it is thought that ACE inhibitors could not suppress chymase-dependent angiotensin II formation, resulting in vascular proliferation in primate and dog vessels, despite the prevention of such proliferation in rats. In the present study the chymase inhibitor significantly suppressed the vascular proliferation, despite the increase of the ACE activity in the grafted veins. The inhibition of chymase, but not ACE, might be useful for preventing the vascular proliferation of grafted veins.

We reported that an angiotensin II type 1 receptor antagonist, L-158,809, suppressed vascular proliferation in dog grafted veins. ${ }^{14}$ In the present study the chymase inhibitor significantly suppressed not only the chymase activity but also total angiotensin II-forming activity in the grafted veins. These findings suggest that total angiotensin II-forming activity in grafted veins depends mainly on the chymase-dependent angiotensin II-forming pathway. Recently, we investigated the activities of the angiotensin II-forming enzymes ACE and chymase in human SVs and ITAs and reported that the chymase activity and total angiotensin IIforming activity were significantly increased in the SV compared with that in the ITA, ${ }^{30}$ suggesting that a higher chymase activity in the SV might play an important role in vein graft diseases.
In conclusion, we confirmed that the chymase inhibitor was effective for the inhibition of chymase activity and intimal hyperplasia in grafted veins for 3 months after bypass surgery and that chymase inhibitors might be useful for preventing intimal hyperplasia in grafted veins.

\section{References}

1. Shelton ME, Forman MB, Virmani R, Bajaj A, Stoney WS, Atkinson JB. A comparison of morphologic and angiographic findings in longterm internal mammary artery and saphenous vein bypass grafts. $J$ Am Coll Cardiol. 1988;11:297-307.

2. Cameron AA, Green GE, Brogno DA, Thornton J. Internal thoracic artery grafts: 20 year clinical follow-up. J Am Coll Cardiol. 1995;25: $188-92$.

3. van Son JA, Falk V, Walther T, Smedts FM, Mohr FW. Low-grade intimal hyperplasia in internal mammary and right gastroepiploic arteries as bypass grafts. Ann Thorac Surg. 1997;63:706-8.

4. Lytle BW, Loop FD, Cosgrove DM, Ratliff NB, Easley K, Taylor PC. Long-term (5 to 12 years) serial studies of internal mammary artery and saphenous vein coronary bypass grafts. $J$ Thorac Cardiovasc Surg. 1985;89:248-58. 
5. de Feyter PJ, van Suylen RJ, de Jaegere PP, Topol EJ, Serruys PW. Balloon angioplasty for the treatment of lesions in saphenous vein bypass grafts. J Am Coll Cardiol. 1993;21:1539-49.

6. Borland JA, Chester AH, Yacoub MH. The renin angiotensin system in bypass graft surgery. Curr Opin Cardiol. 2000;15:371-7.

7. Suma H. Arterial grafts in coronary bypass surgery. Ann Thorac Cardiovasc Surg. 1999;5:141-5.

8. Sato T, Isomura T, Suma H, Horii T, Kikuchi N. Coronary artery bypass grafting with gastroepiploic artery composite graft. Ann Thorac Surg. 2000;69:65-9.

9. Kim S, Iwao H. Molecular and cellular mechanisms of angiotensin II-mediated cardiovascular and renal diseases. Pharmacol Rev. 2000; 52:11-34.

10. Takai S, Jin D, Sakaguchi M, Miyazaki M. Chymase-dependent angiotensin II formation in human vascular tissue. Circulation. 1999; 100:654-8.

11. Takai S, Shiota N, Kobayashi S, Matsumura E, Miyazaki M. Induction of chymase that forms angiotensin II in the monkey atherosclerotic aorta. FEBS Lett. 1997;412:86-90.

12. Caughey GH, Raymond WW, Wolters PJ. Angiotensin II generation by mast cell alpha- and beta-chymases. Biochim Biophys Acta. 2000; 1480:245-57.

13. Takai S, Shiota N, Yamamoto D, Okunishi H, Miyazaki M. Purification and characterization of angiotensin II-generating chymase from hamster cheek pouch. Life Sci. 1996;58:591-7.

14. Yuda A, Takai S, Jin D, Sawada Y, Nishimoto M, Matsuyama N, et al. Angiotensin II receptor antagonist, L-158,809, prevents intimal hyperplasia in dog grafted veins. Life Sci. 2000;68:41-8.

15. Takai S, Yuda A, Jin D, Nishimoto M, Sakagichi M, Sasaki S, et al. Inhibition of chymase reduces vascular proliferation in dog grafted veins. FEBS Lett. 2000;467:141-4.

16. Nishimoto M, Takai S, Kim S, Jin D, Yuda A, Sakaguchi M, et al. Significance of chymase-dependent angiotensin II-forming pathway in the development of vascular proliferation. Circulation. 2001;104:1274-9.

17. Oleksyszyn J, Powers JC. Amino acid and peptide phosphonate derivatives as specific inhibitors of serine peptidases. Methods Enzymol. 1994;244:423-41.

18. Craig SS, Schwartz LB. Human MCTC type of mast cell granule: the uncommon occurrence of discrete scrolls associated with focal absence of chymase. Lab Invest. 1990;63:581-5.
19. McEuen AR, Sharma B, Walls AF. Regulation of the activity of human chymase during storage and release from mast cells: the contributions of inorganic cations, $\mathrm{pH}$, heparin and histamine. Biochim Biophys Acta. 1995;1267:115-21.

20. Zhang S, Anderson DF, Bradding P, Coward WR, Baddeley SM, MacLeod JD, et al. Human mast cells express stem cell factor. J Pathol. 1998;186:59-66.

21. Majesky MW, Lindner V, Twardzik DR, Schwartz SM, Reidy MA. Production of transforming growth factor beta 1 during repair of arterial injury. J Clin Invest. 1991;88:904-10.

22. Kim S, Kawamura M, Wanibuchi H, Ohta K, Hamaguchi A, Omura T, et al. Angiotensin II type 1 receptor blockade inhibits the expression of immediate-early genes and fibronectin in rat injured artery. Circulation. 1995;92:88-95.

23. Tazawa S, Nakane T, Chiba S. Angiotensin II type 1 receptor blockade prevents up-regulation of angiotensin II type $1 \mathrm{~A}$ receptors in rat injured artery. J Pharmacol Exp Ther. 1999;288:898-904.

24. Powell JS, Clozel JP, Muller RK, Kuhn H, Hefti F, Hosang M, et al. Inhibitors of angiotensin converting enzyme prevent myointimal proliferation after vascular injury. Science. 1989;245:186-8.

25. MERCATOR Study Group. Does the new angiotensin converting enzyme inhibitor cilazapril prevent restenosis after percutaneous transluminal coronary angioplasty? Results of the MERCATOR study. Circulation. 1992;86:100-10.

26. Roux SP. Clozel JP, Kuhn H. Cilazapril inhibits wall thickening of vein bypass graft in the rat. Hypertension. 1991;18(suppl 4):II43-6.

27. Hanson SR, Powell JS, Dodson T, Lumsden A, Kelly AB, Anderson JS, et al. Effects of angiotensin converting enzyme inhibition with cilazapril on intimal hyperplasia in injured arteries and vascular grafts in the baboon. Hypertension. 1991;18(suppl 4):II70-6.

28. Miyazaki M, Shiota N, Sakonjo H, Takai S. Angiotensin II type 1 receptor antagonist, TCV-116, prevents neointima formation in injured arteries in the dog. Jpn J Pharmacol. 1999;79:455-60.

29. Miyazaki M, Wada T, Shiota N, Takai S. Effect of an angiotensin II receptor antagonist, candesartan cilexetil, on canine intima hyperplasia after balloon injury. J Hum Hypertens. 1999;13(suppl 1):S21-5.

30. Nishimoto M, Takai S, Sawada Y, Yuda A, Kondo K, Yamada M, et al. Chymase-dependent angiotensin II formation in the saphenous vein versus the internal thoracic artery. J Thorac Cardiovasc Surg. 2001; 121:729-34. 